\title{
PESANTREN SEBAGAI HABITUS PERADABAN ISLAM INDONESIA
}

\section{Siti Ma'rifah dan Muhamad Mustaqim}

Lembaga Kajian Sosial dan Agama Tasamuh Institute Kudus, Jawa Tengah, Indonesia STAIN Kudus, Jawa Tengah, Indonesia ma'rifah55@gmail.com,muhamadmustaqim10@gmail.com

\begin{abstract}
ISLAMIC BOARDING SCHOOL AS CIVILIZATION HABITUS INDONESIAN ISLAM. Islamic boarding school is a native and traditional Islamic education system which has been there along with the arrival of Islam in Indonesia. The existence of Islamic boarding schools as part of the Islamic teaching becomes the pulse of the development of Islam itself. Thus, the Islamic boarding school is an original education system that has formed Muslim religious and social behavior from generation to generation. Civilization and culture of society is formed by the social behaviors which have been internalized into a social structure. This behavior, according to Bourdieu, called the habitus. Habitus in this case created through the process of socialization of values that lasts longer, so it settles into a way of thinking and behavior patterns that persist in the buman self. If we follow this reasoning, then Islamic boarding school is a social habitus formed in Muslim behavior patterns in social life. As habitus, Islamic boarding schools have a system of values inherited from generation to generation. In this paper, it was obtained some of the value system of education and civilization made up by the Islamic boarding schools, including modesty, the preservation of traditions, culture science, and nationalism.
\end{abstract}

Keywords: Islamic Boarding School, Habitus, Social Behavior. 


\begin{abstract}
Abstrak
Pesantren merupakan sistem pendidikan Islam tradisional dan pribumi yang telah ada seiring dengan datangnya Islam di Indonesia. Keberadaan pesantren sebagai bagian dari pengajaran ajaran Islam menjadi denyut nadi perkembangan Islam itu sendiri. Sebingga, pesantren merupakan sistem pendidikan original yang telah membentuk keberagamaan dan perilaku masyarakat Muslim dari generasi ke generasi. Peradaban dan budaya masyarakat terbentuke oleh laku-laku sosial yang telah terinternalisasi ke dalam sebuah struktur sosial. Laku ini, menurut Bourdieu, disebut dengan habitus. Habitus dalam hal ini tercipta melalui proses sosialisasi nilai-nilai yang berlangsung lama, sehingga mengendap menjadi cara berpikir dan pola perilaku yang menetap di dalam diri manusia tersebut. Jika mengikuti alur berpikir ini, maka pesantren merupakan habitus sosial yang terbentuk dalam pola prilaku Muslim dalam kehidupan sosialnya. Sebagai habitus, pesantren mempunyai sistem nilai yang terwariskan dari generasi ke generasi. Dalam tulisan ini, didapatkan beberapa sistem nilai pendidikan dan peradaban yang terbangun oleh pesantren, di antaranya kebersahajaan, pelestarian tradisi, budaya keilmuan, dan nasionalisme.
\end{abstract}

Kata Kunci: Pesantren, Habitus, Perilaku Sosial.

\title{
A. Pendahuluan
}

Dalam sebuah pidato, Barack Obama pernah mengatakan bahwa Indonesia adalah salah satu negara dengan penduduk moyoritas Muslim yang toleran. Pernyataan ini kiranya bukan tanpa alasan, mengingat keberadaan masyarakat Indonesia yang multikultur, namun dapat hidup bersama secara damai. Berbicara tentang masyarakat Indonesia, maka tidak bisa lepas dari keberadaan masyarakat Muslim, yang merupakan penduduk mayoritas hampir 90\% dari jumlah total penduduk Indonesia. Masyarakat Muslim sebagai mayoritas mempunyai semangat toleran yang tinggi untuk hidup bersama secara damai dengan masyarakat lainnya.

Kecenderungan masyarakat Muslim seperti ini tentunya tidak semata-mata ada dengan sendirinya, namun terbangun oleh 
tradisi historis yang menjadi konstruk peradaban. Keberadaan masyarakat Muslim hari ini terbangun oleh sejarah panjang perkembangan Islam yang mengitarinya. Agama Islam bukanlah agama asli yang dianut oleh masyarakat pribumi, melainkan agama "pendatang" yang mempunyai perbedaan tradisi dan platform dengan tradisi lokal. Sehingga, internalisasi ajaran Islam dalam pembentukan perilaku dan peradaban masyarakat mengalami dinamika historis yang tak terelakkan. Islam yang dalam catatan sejarah telah masuk wilayah Indonesia pada abad ke-12 M mengalami pasang surut perkembangan yang menawarkan karakter tersendiri bagi terbentukkan platform Islam sekarang ini.

Proses internalisasi ajaran agama membutuhkan wahana yang mampu melakukan tugas ini. Pendidikan, dalam hal ini, adalah wahana nyata dan ideal dalam penginternalisasian ajaran agama kepada masyarakat Muslim. Melalui pendidikan Islam inilah internalisasi dan pewarisan nilai dari generasi ke generasi dimapankan. Bak mata rantai panjang sejarah, nilai itu sampai saat ini menjelma menjadi sistem nilai yang diapakai oleh umat saat ini.

Membahas pendidikan Islam, maka tidak bisa dilepaskan dari sistem pendidikan klasik yang dikenal dengan nama pesantren. Pesantren merupakan sistem pendidikan Islam tradisional dan pribumi yang telah ada seiring dengan datangnya Islam. Keberadaan pesantren sebagai bagian dari pengajaran ajaran Islam menjadi denyut nadi perkembangan Islam itu sendiri. Sehingga, pesantren merupakan sistem pendidikan original yang telah membentuk keberagamaan dan perilaku masyarakat Muslim dari generasi ke generasi. Dengan sisitem pengajaran yang tradisional dan non-formal, pesantren telah memberikan konstribusi yang besar atas penanaman nilai-nilai dan ajaraan Islam ke dalam benak masyarakat Muslim. Bahkan, dengan dakwah ala pesantren inilah para ulama penyebar agama Islam dapat diterima dengan mudah oleh penduduk pribumi pada saat itu. 
Walisongo dalam hal ini boleh jadi adalah founding father pesantren dan Islam di Indonsia, khusunya di Jawa. Melalui pendekatan dakwah yang lebih akulturatif tehadap tradisi dan budaya lokal, para Walisongo mampu memikat hati masyarakat pribumi pada saat itu dengan tanpa meninggalkan dan menghapus warisan tradisi lokal. Kearifan ini menjadi titik lahir pola dakwah pesantren sebagiai bagian dakwah Islam dalam aspek pendidikan.

Sampai di sini, tampaknya tidak dapat diingkari lagi bahwa pesantren merupakan sistem dan tradisi Islam pribumi yang hari ini telah membentuk perilaku dan keberagamaan masyarakat Muslim di Indonesia. Meminjam istilah Piere Bordieu, habitus masyarakat Indonesia saat ini, dibangun oleh sebuah multi sistem yang menginternalisasi ke dalam benak masyarakat. Dan, pesantren adalah bagian dari sistem dominan yang telah membangun habitus peradaban masyarakat, sehingga menampilkan peradaban Islam Indonesia yang humanis dan toleran. Artinya, tradisi pesantren yang sudah terbangun selam berabad-abad lamanya telah mampu membentuk habitus masyarakat Indonesia dari generasi ke generasi. Dengan kata lain, peradaban Islam Indonesia yang saat ini terbangun, dengan corak ekletik dan toleran, tidak bisa lepas dari peran pesantren sebagai sistem pembangunan nilai dan karakter melalui pendidikan.

\section{B. Pembahasan}

\section{Sejarah Pesantren}

Pesantren adalah bentuk pendidikan tradisional di Indonesia yang sejarahnya telah mengakar selama berabad-abad. Keberadaan pesantren sejalan dengan dinamika pendidikan Islam di Nusantara. Mengenai awal kemunculan pesantren ini, ada beberapa pandangan. Abdurrahman Mas'ud, misalnya, memandang bahwa keberadaan pesantren tidak lepas dari peran 
Walisongo, figur penyebar agama Islam di Jawa. ${ }^{1}$ Walisongo punya peran besar dalam pengembangan ajaran Islam, yang secara tradisional terlembagakan melalui lembaga pendidikan Islam tradisional. Pesantren Ampel merupakan cikal bakal berdirinya pesantren-pesantren di tanah air. Sebab, para santri setelah menyelesaikan studinya merasa berkewajiban mengamalkan ilmunya di daerahnya masing-masing. Maka, didirikanlah pondokpondok pesantren dengan mengikuti pada apa yang mereka dapatkan di Pesantren Ampel.

Pesantren merupakan lembaga pendidikan Islam yang unik di Indonesia. Lembaga pendidikan ini telah berkembang khususnya di Jawa selama berabad-abad. Maulana Malik Ibrahim (meninggal 1419 di Gresik Jawa Timur), spiritual father Walisongo, dalam masyarakat santri Jawa dipandang sebagai gurunya guru tradisi pesantren di tanah Jawa. ${ }^{2}$

Adapun Nurcholish Madjid menyebutkan bahwa pesantren mengandung makna keislaman sekaligus keaslian (indigenous) Indonesia. Kata "pesantren" mengandung pengertian sebagai tempat para santri atau murid pesantren, sedangkan kata "santri" diduga berasal dari istilah Sansekerta "sastri” yang berarti "melek huruf", atau dari bahasa Jawa "cantrik" yang berarti orang yang mengikuti gurunya ke mana pun pergi. Dari sini kita memahami bahwa pesantren setidaknya memiliki tiga unsur, yakni santri, kiai, dan asrama. ${ }^{3}$

Dari catatan sejarah, lembaga pendidikan pesantren tertua adalah Pesantren Tegalsari di Ponorogo, yang didirikan pada tahun 1724. Namun, sekitar seabad kemudian, yakni melalui survey Belanda tahun 1819, tampak sekali bahwa pesantren tumbuh dan berkembang secara sangat pesat, terutama di seluruh

\footnotetext{
1 Abdurrahman Mas'ud, dkk., Dinamika Pesantren dan Madrasah (Yogyakarta: Pustaka Pelajar, 2002), hlm. 4.

${ }^{2}$ Saifuddin Zuhri, Sejarah Kebangkitan Islam dan Perkembangannya di Indonesia (Bandung: al-Ma'arif, 1979), hlm. 263.

${ }^{3}$ Nurcholish Madjid, Bilik-bilik Pesantren (Jakarta: Paramadina, 1997), hlm. 67.
} 
pelosok pulau Jawa. Survey itu melaporkan lembaga pendidikan ini sudah terdapat di Priangan, Pekalongan, Rembang, Kedu, Surabaya, Madiun, dan Ponorogo. Islamis asal Belanda, Martin van Bruinessen yakin bahwa sebelum abad ke-18 atau sebelum berdirinya Pesantren Karang, belum ada lembaga yang layak disebut pesantren. Yang ada hanyalah tempat pengajaran perorangan atau tidak terstruktur.

Sejak awal masuknya Islam ke Indonesia, pendidikan Islam merupakan kepentingan tinggi bagi kaum Muslimin. Akan tetapi, hanya sedikit sekali yang dapat kita ketahui tentang perkembangan pesantren di masa lalu, terutama sebelum Indonesia dijajah Belanda, karena dokumentasi sejarah sangat kurang. Bukti yang dapat kita pastikan menunjukkan bahwa pemerintah penjajahan Belanda memang membawa kemajuan teknologi ke Indonesia dan memperkenalkan sistem dan metode pendidikan baru. Namun, pemerintahan Belanda tidak melaksanakan kebijaksanaan yang mendorong sistem pendidikan yang sudah ada di Indonesia, yaitu sistem pendidikan Islam.

Pada tahun 1882, pemerintah Belanda mendirikan Priesterreden (Pengadilan Agama) yang bertugas mengawasi kehidupan beragama dan pendidikan pesantren. Tidak begitu lama setelah itu, dikeluarkan Ordonansi Tahun 1905 yang berisi peraturan bahwa guru-guru agama yang akan mengajar harus mendapatkan izin dari pemerintah setempat. Peraturan yang lebih ketat lagi dibuat pada tahun 1925 yang membatasi siapa yang boleh memberikan pelajaran mengaji. Akhirnya, pada tahun 1932 peraturan dikeluarkan yang dapat memberantas dan menutup madrasah dan sekolah yang tidak ada izinnya atau yang memberikan pelajaran yang tak disukai oleh pemerintah. ${ }^{4}$

Peraturan-peraturan tersebut membuktikan kekurangadilan kebijaksanaan pemerintah penjajahan Belanda

${ }^{4}$ Zamakhsyari Dhofier, Tradisi Pesantren: Studi Tentang Pandangan Hidup Kyai (Jakarta: LP3ES, 1985), hlm. 41; Zuhairini, dkk., Sejarab Pendidikan Islam (Jakarta: Bumi Aksara, 1997), hlm. 149. 
terhadap pendidikan Islam di Indonesia. Namun demikian, pendidikan pondok pesantren juga menghadapi tantangan pada masa kemerdekaan Indonesia. Setelah penyerahan kedaulatan pada tahun 1949, pemerintah Republik Indonesia mendorong pembangunan sekolah umum seluas-luasnya dan membuka secara luas jabatan-jabatan dalam administrasi modern bagi bangsa Indonesia yang terdidik dalam sekolah-sekolah umum tersebut. Dampak kebijaksanaan tersebut adalah bahwa kekuatan pesantren sebagai pusat pendidikan Islam di Indonesia menurun. Ini berarti bahwa jumlah anak-anak muda yang dulu tertarik kepada pendidikan pesantren menurun dibandingkan dengan anak-anak muda yang ingin mengikuti pendidikan sekolah umum yang baru saja diperluas. Akibatnya, banyak sekali pesantrenpesantren kecil mati sebab santrinya kurang cukup banyak. ${ }^{5}$

Jika kita melihat peraturan-peraturan tersebut, baik yang dikeluarkan pemerintah Belanda selama bertahun-tahun maupun yang dibuat pemerintah RI, memang masuk akal untuk menarik kesimpulan bahwa perkembangan dan pertumbuhan sistem pendidikan Islam, dan terutama sistem pesantren, cukup pelan karena ternyata sangat terbatas. Akan tetapi, apa yang dapat disaksikan dalam sejarah adalah pertumbuhan pendidikan pesantren yang kuatnya dan pesatnya luar biasa. ${ }^{6}$

Dalam karya monumentalnya, Kitab Kuning, Indonesianis asal Negeri Kincir Angin, Martin van Bruinessen menulis, munculnya pesantren adalah untuk mentransmisikan Islam tradisional sebagaimana yang terdapat dalam kitab-kitab klasik yang ditulis berabad-abad lalu. Dengan kata lain, tradisi, baik tradisi pemikiran maupun lelaku yang berkembang di pesantren, tak lain merupakan implementasi ajaran-ajaran yang terkandung dalam kitab-kitab klasik itu. Pengembangan Islam di Indonesia tidak dilewati oleh gerakan dunia ini dan buktinya bisa dilihat dengan pendirian satu diantara dua organisasi Islam di Indonesia

\footnotetext{
${ }^{5}$ Zamakhsyari Dhofier, Tradisi Pesantren, hlm. 41.

${ }^{6}$ Zuhairini, dkk., Sejarah Pendidikan Islam, hlm. 150.
} 
yang paling memengaruhi namanya Muhammadidyah, pada tahun 1912. Muhammadiyah didirikan di Jawa Timur sebagai wahana untuk memajukan suatu aliran Islam yang "modernis" atau "reformis". Dalam beberapa instansi, organisasi Muhammadiyah melawan dan merancam norma-norma dan nilainya Islam yang tradisional yang hingga saat itu lebih dominan di seluruh Jawa.

Pada tahun1926, satu organisasi namanya Nahdlatul Ulama (NU) didirikan untuk melindungi kepercayaannya Islam yang "tradisional", yaitu yang lebih memperbolehkan orangorang mencampurkan kepercayaan Islamnya dengan kepercayaan adat atau tradisional. Sekarang Nahdlatul Ulama mempunyai jumlah anggota yang sebesar 40 juta dan Muhammadiyah sekitar 20 juta.

Dengan pendirian Muhammadiyah dan penyebaran pendekatan Islam di Indonesia yang modernis atau reformis, kita lihat bahwa Muhammadiyah yang memperkenalkan model sekolah Islam yang modern dan yang berusaha mengambil pelajaran Islamnya langsung dari al-Qur'an dan Sunnah. ${ }^{7}$ Di sisi lain, NU tetap mendirikan dan mempertahankan model pesantrennya yang lebih tradisional dan sinkretis. Bahkan, pesantren-pesantren NU merupakan foundasi organisasi ini. Baik NU maupun Muhammadiyah tetap merupakan organisasi Islam yang paling penting dan memengaruhi di Indonesia, bahkan organisasi Muslim yang terbesar di dunia.

Dalam usaha menjembati kesenjangan di antara pendekatannya Muhammadiyah dan model pesantren NU yang tradisional, pesantren modern Gontor didirikan pada tahun 1926 dan menjadi contoh untuk pesantren-pesantren lain yang reformis atau yang ingin berdiri di luar payung NU dan Muhammadiyah. Melalui dua ormas ini, pesantren mengalami perkembangan yang cukup signifikan, dengan bentuk corak yang dimiliki masing-masing. Saat ini pesantren secara khusus ditangani

${ }^{7}$ Nawawi, "Sejarah Perkembangan Pesantren", Jurnal Ibda, STAIN Purwokerto, 2006, hlm. 56. 
oleh pemerintah melalui Kementerian Agama di bawah naungan Direktorat Pondok Pesantren.

\section{Habitus Masyarakat}

Istilah habitus mungkin menjadi perbendaharaan yang asing dalam diskursus kebahasaan secara umum. Namun, dalam konteks sosiologi, term habitus merupakan term penting dalam pemaknaan realitas sosial. Istilah ini merupakan pengejawantahan bagi pembentukan tradisi dan karakter sosial sebuah masyarakat.

Adalah Bourdieu yang merumuskan konsep habitus sebagai analisis sosiologis dan filsafati atas perilaku manusia. Dalam arti ini, habitus adalah nilai-nilai sosial yang dihayati oleh manusia, dan tercipta melalui proses sosialisasi nilai-nilai yang berlangsung lama, sehingga mengendap menjadi cara berpikir dan pola perilaku yang menetap di dalam diri manusia tersebut. Sehingga, habitus merupakan praktik pengungkapan perwatakan dalam ruang sosial, di mana terdapat medan sosial, yang di dalamnya setiap anggota membentuk suatu sistem hubungan yang didasarkan atas pertaruhan yang bermakna dan diinginkan. ${ }^{8}$

Pierre Felix Bourdieu adalah salah seorang pemikir Prancis paling terkemuka yang dikenal sebagai sosiolog, antropolog, dan pada masa akhir hidupnya dikenal sebagai jawara pergerakan antiglobalisasi. Karyanya memiliki bahasan yang luas mulai dari etnografi dan seni, sastra, pendidikan, bahasa, selera kultural dan televisi. Bordieu lahir pada tanggal 1 Agustus 1930 di Desa Denguin, Distrik Pyreness-Antlantiques, barat daya Prancis. Ia adalah putra seorang pegawai pos desa. Ia menjalani pendidikan SMA (Lycee) di Pau sebagai siswa yang cemerlang dan terkenal di sekolahannya sebagai bintang rugby. Ia kemudian pindah ke Lycee louis-le-Grand di Paris. Dari sinilah d bisa diterima masuk Ecole Normale Superieure dan belajar filsafat kepada Louis Althusser. Pada saat itu Bourdieu tertarik pada pemikiran Marleau-Ponty,

${ }^{8}$ Johh Lechte, 50 Filsuf Kontemporer (Yogyakarta: Kanisius, 2001), hlm. 83 . 
Husserl. Dan, ia telah membaca karya Heiddegger Being and Time dan tulisan Marx muda untuk kepentingan akademisnya. Tesisnya pada tahun 1953 merupakan terjemahan dan ulasan Animadversiones karya Leibniz.

Bourdieu dikenal pertama-tama sebagai seorang sosiolog yang mencoba menyelesaikan ketegangan yang ada dalam Marxisme ortodoks antara basis dan super-struktur atau antara ekonomi dan kebudayaan. Dalam pandangan Bourdieu, ilmu ekonomi selama ini membatasi dirinya hanya pada produksi serta pertukaran barang dan jasa. Di lain pihak, kebudayaan hanya berurusan dengan nilai-nilai. Menurut Bourdieu, pandangan itu harus diubah secara radikal, karena produksi dan pertukaran terjadi bukan hanya pada barang dan jasa, tetapi juga pada bidang kebudayaan dan bidang sosial.

Secara lebih mendetail, terminologi habitus dapat diuraikan dalam beberapa proposisi berikut.

a. Habitus adalah sistem atau perangkat disposisi yang bertahan lama dan diperoleh melalui latihan berulang kali.

b. Ia lahir dari kondisi sosial tertentu dan karena itu menjadi struktur yang sudah diberi bentuk terlebih dahulu oleh kondisi sosial di mana dia diproduksikan.

c. Ia berfungsi sebagai kerangka yang melahirkan dan memberi bentuk kepada persepsi, representasi, dan tindakan seseorang dan karena itu menjadi structuring structures.

d. Sekalipun habitus lahir dalam kondisi sosial tertentu, ia bisa dialihkan ke kondisi sosial yang lain dan karena itu bersifat transposable.

e. Habitus bersifat pra-sadar (pre-conscious) karena ia tidak merupakan hasil dari refleksi atau pertimbangan rasional. Ia lebih merupakan spontanitas yang tidak disadari dan tidak dikehendaki dengan sengaja, tetapi juga bukanlah suatu gerakan mekanistis yang tanpa latar belakang sejarah sama sekali. 
f. Ia bersifat teratur dan berpola, tetapi bukan merupakan ketundukan kepada peraturan-peraturan tertentu.

g. Habitus dapat terarah kepada tujuan dan hasil tindakan tertentu, tetapi tanpa ada maksud secara sadar untuk mencapai hasil-hasil tersebut dan juga tanpa penguasaan kepandaian yang bersifat khusus untuk mencapainya.

Uraian tersebut menunjukkan bahwa habitus menjadi kerangka acuan yang mendasari perilaku sebuah masyarakat. Sehingga, berbagai tindakan dan perilaku sosial pada dasarnya digerakkan oleh habitus yang telah terbentuk dan berlangsung lama. Habitus ini berbeda dengan pola budaya (cultural patterns), sebagaimana yang dikenal dalam terminologi sosiologi selama ini. Perbedaan utamanya adalah bahwa dalam pandangan antropologi budaya, kebudayaan sudah diterima sebagai given, sedangkan dalam habitus sangat ditekankan proses pembentukannya melalui latihan berulang kali (inculcation). Di sini, habitus terbangun dari sebuah pengalaman sosialisasi awal, di mana struktur luar terinternalisasi ke dalam sebuah sistem sosial. ${ }^{9}$

Menurut Bourdieu, habitus adalah struktur kognitif yang memperantarai individu dalam berurusan dengan realitas sosial. ${ }^{10}$ Manusia dibekali oleh sederetan skema yang terinternalisasi dan melalui skema-skema itu mereka mempersepsi, memahami, menghargai, serta mengevaluasi realitas sosial. Habitus bisa dikatakan sebagai ketidaksadaran-kultural, yakni pengaruh sejarah yang secara tak sadar dianggap alamiah. Ketika membicarakan tentang habitus, maka oleh Bourdieu tidak bisa dipisahkan dengan field (ranah). Field diartikan sebagai jaringan relasi antar posisiposisi objektif dalam suatu tatanan sosial yang hadir terpisah dari kesadaran dan kehendak individual. Field bukan merupakan ikatan intersubjektif antar individu, tetapi semacam hubungan yang

${ }^{9}$ David Swartz, Culture and Poer: the Sociology of Pierre Bourdueu (Chicago: The University of Chicago,1997), hlm. 103.

${ }^{10}$ George Ritzer, Sociological Theory (Singapore: The McGraw-Hill Companies, 1960), hlm. 110. 
terstruktur serta tanpa disadari mengatur posisi-posisi individu dan kelompok dalam tatanan masyarakat yang terbentuk secara spontan. Habitus memungkinkan manusia hidup dalam keseharian mereka secara spontan dan melakukan hubungan dengan pihakpihak di luar dirinya. Dalam proses interaksi dengan pihak luar itu, terbentuklah jaringan relasi posisi-posisi objektif itu.

Ada semacam aturan yang tidak terucapkan dalam setiap field. Aturan yang bekerja sebagai modus sebagai kekerasan simbolik (symbolic violence). Dengan konsep ini, ia ingin memperlihatkan bentuk yang tersembunyi dalam kegiatan sehari-hari. Kekerasan dalam bentuknya yang sangat halus, kekerasan yang dikenakan pada agen-agen sosial tanpa mengundang resistensi, sebaliknya malah mengundang konformitas, sebab sudah mendapat legitimasi sosial karena bentuknya yang sangat halus.

Habitus adalah struktur kognitif yang memperantarai individu dan realitas sosial. Habitus juga merupakan struktur subjektif yang terbentuk dari pengalaman individu berhubungan dengan individu lain dalam jaringan struktur objektif yang ada di dalam ruang sosial. Habitus diindikasikan sebagai skema-skema yang merupakan perwakilan konseptual dari benda-benda dalam realitas sosial. Dalam perjalanan hidupnya, manusia memiliki skema yang terinternalisasi dan melalui skema-skema itu mereka mempersepsi, memahami, menghargai, serta mengevaluasi realitas sosial.

Habitus juga dapat dikatakan sebagai ketidaksadaran kultural, yakni pengaruh sejarah yang tidak disadari dianggap alamiah. Oleh karena itu, habitus bukanlah pengetahuan ataupun ide bawaan. Habitus bagi Bourdieau lebih sebagai gugus kesadaran moral yang tumbuh dari proses internalisasi sosio-moral akan nilai kebaikan demi cinta, penghormatan, dan pengakuan akan sesama. Sehingga, ia merupakan produk sejarah yang terbentuk setelah manusia lahir dan berinteraksi dengan masyarakat dalam ruang dan waktu tertentu. 
Habitus merupakan hasil pembelajaran melalui pengasuhan aktivitas bermain, belajar, dan pendidikan masyarakat di dalam arti luas. Pembelajaran yang dilakukan terkadang tidak kita sadari dan secara halus dan tampil sebagai sesuatu yang wajar, sehingga akan kelihatan alamiah atau berasal dari sananya. Habitus juga mencakup pengetahuan dan pemahaman seseorang mengenai dunia yang memberikan konstribusi tersendiri pada realitas dunia itu. Habitus juga berubah-ubah yang mengupayakan adanya kompromi dengan kondisi material. Hal ini akan memberikan konstribusi baru untuk membangun sebuah prinsip baru untuk memunculkan sebuah praktik di dalam individu.

Bourdie menekankan bahwa habitus adalah konstruksi perantara bukan konstruksi yang mendeterminasi. Habitus juga merupakan sebuah sifat yang tercipta karena kebutuhan. Habitus berhubungan dengan harapan-harapan dalam kaitannya dalam bentuk modal yang secara erat diimbangi dengan berbagai kemungkinan objektif.

Relevansi habitus dalam tulisan ini adalah kerangka paradigmatik untuk mendalami peran entitas sosial dalam membentuk struktur sosial. Struktur sosial ini kemudian menyatu dengan karakter masyarakat yang melestari menjadi sebuah tipologi. Dalam konteks keberagamaan masyarakat, pesantren barang kali merupakan "habitus" yang melembaga ke dalam struktur sosial masyarakat Muslim di Indonesia. Struktur ini berlangsung melintasi ruang waktu, dengan berbagai gesekan, anomali, dan akulturasi. Namun, karakter dasar yang dimainkan oleh habitus tersebut tidak pernah hilang dan "roh" beragama masyarakat. Karakter inilah yang barang kali membedakan corak keberagamaan dengan komunitas masyarakat lainnya.

\section{Pesantren dan Pembentukan Habitus Peradaban}

Dalam perkembangannya, pesantren telah melahirkan berbagai produk budaya yang bercorak keberagamaan. Budaya tersebut perlahan menjadi sebuah sistem nilai yang menjadi 
habitus masyarakat dalam kehidupannya. Ada beberapa sistem nilai yang terbangun dari pesantren ini, di antaranya sebagai berikut.

\section{a. Kebersahajaan}

Pesantren lahir dari kultur tradisional, di mana nilai-nilai kultur setempat menjadi acuan dari perilaku keberagamaannya. Dalam konteks ini, nilai sederhana dan sahaja adalah bagian dari upaya membangun karakter dalam proses pembelajaran agama. Kaum santri dikenal sebagai kaum bersarung. Sarung adalah sebuah identitas kesederhanaan yang jauh dari kesan mewah dan modern. Pesantren salaf/tradisional adalah lembaga pesantren yang mempertahankan pengajaran kitab-kitab klasik sebagai inti pendidikan. Sistem madrasah ditetapkan hanya untuk memudahkan sistem sorogan yang dipakai dalam lembagalembaga pengajian bentuk lama, tanpa mengenalkan pengajaran pengetahuan umum. Sistem sorogon dan bandongan adalah sistem pembelajaran yang sangat sederhana, namun memiliki makna yang besar dalam pembelajaran dan peningkatan kemampuan santri.

\section{b. Pertahanan Budaya (Cultural Resistance)}

Karakter pesantren yang identik dengan nilai tradisional memberikan roh bagaimana pesantren melestarikan budaya dan tradisi yang ada. Mempertahankan budaya dan tetap bersandar pada ajaran dasar Islam adalah budaya pesantren yang sudah berkembang berabad-abad. Ide cultural resistance juga mewarnai kehidupan intelektual dunia pesantren. Subjek yang diajarkan di lembaga ini melalui hidayah dan berkah seorang kiai sebagai guru utama atau irsyadu ustäin adalah kitab klasik atau kitab kuning, diolah dan ditransmisikan dari satu generasi ke generasi berikut. ${ }^{11}$ Sehingga, tradisi ini selalu terwariskan, di mana generasi penerimanya selalu melestarikan warisan tradisi tersebut.

Karena konsep pertahanan budaya pula dunia pesantren selalu tegar menghadapi hegemoni dunia luar. Sejarah

${ }^{11}$ Abdurrahman Mas'ud, dkk., Dinamika Pesantren dan Madrasah, hlm. 30. 
menunjukkan bahwa saat penjajah semakin menindas, saat itu pula perlawanan kaum santri semakin keras. Penolakan Sultan Agung dan Diponegoro terhadap kecongkakan Belanda, ketegaran kiaikiai pada masa penjajahan, serta kehati-hatian pemimpin Islam berlatar belakang pesantren dalam menyikapi kebijakan penguasa yang dirasakan tidak bijaksana atau sistem yang established sehingga menempatkan mereka sebagai kelompok "oposan" adalah bentuk-bentuk cultural resistance dari dulu hingga sekarang. ${ }^{12}$

Sampai sini pesantren mampu menghadirkan tradisi pada masa kekinian, karena jejaring pelestarian yang selalu terjaga dan melekat dalam kultur pesantren. Hal ini yang sekiranya menarik, mengingat penetrasi modernitas yang kian gencar, yang sering kali membawa nilai-nilai tradisi Barat yang jauh dari nilai agama. Pesantren dalam konteks ini memberikan semacam sistem nilai, yang mampu membentuk karakter masyarakat penganutnya untuk tidak mudah terbuai dengan budaya baru.

\section{c. Budaya Keilmuan yang Tinggi}

Sebagaimana hakikat eksistensinya, pesantren adalah lembaga pendidikan keagamaan. Berbagai ilmu agama diajarkan dengan berbagai referensi dan kecenderungan aliran sehingga menghasilkan budaya keilmuan yang tinggi. Karena untuk dinyatakan lulus, seorang santri harus menguasai kitab-kitab tertentu yang dijadikan panduan dalam sebuah pesantren. Bahkan tak jarang, para santri ini harus menghafal penuh atau sebagiaan isi kitab tertentu. Ini adalah bukti bahwa pesantren mengajarkan budaya intelektual yang tinggi.

Bahkan, ada istilah wandering santris (santri kelana) di mana para santri dianjurkan untuk melakukan perjalanan untuk berguru ke berbagai pesantren atau kiai. Sebagai contoh, dua tokoh besar dalam tradisi pesantren di Indonesia, yakni al-Bantani dan atTirmisi mengembara sepanjang hidupnya dan menjadi guru besar di Mekah dan Madinah, dua kota yang merupakan sumber

${ }^{12}$ Ibid., hlm. 31. 
peradaban Islam. ${ }^{13}$ Tradisi ini sampai sekarang masih berlaku di beberapa santri. Ada semacam keyakinan bahwa belum afdal jika belum nyantrik di beberapa kiai. Di dunia pesantren juga dikenal spesialisasi ilmu. Beberapa kiai mempunyai spesifikasi keilmuan tertentu yang sangat expert di bidangnya. Sehingga, seorang santri akan dianggap menguasai betul bidang keilmuan tertentu jika nyantri ke kiai tertentu.

\section{d. Nasionalisme}

Kaum santri memiliki karakter ketaatan yang sangat kuat terhadap kiai. Ketaatan ini merupakan wujud sikap beragama, di mana kiai dipandang sebagai orang yang memiliki pemahaman akan kitab suci secara baik. Selain itu, penghargaan terhadap ahli ilmu, orang yang memiliki banyak ilmu, juga merupakan inti ajaran Islam, yang juga menjadi sumber ketaatan. Dalam hal ini, Sayyidina Ali pernah berkata, "Aku merupakan budak (hamba) bagi orang yang mengajariku satu huruf dari al-Qur'an". Ketertundukan kepada kiai atau guru inilah yang menyebabkan para santri akan melakukan apa saja yang diperintahkan oleh sang kiai tersebut, karena menganggap adanya kadar kebenaran yang tersirat dari perintah tersebut.

Nasionalisme santri dalam hal ini misalnya bisa dibuktikan melalui momentum Resolusi Jihad 1945. Aplikasi jihad sebagai sebuah titah para kiai yang dimotori oleh K.H. Hasyim Asy'ari selaku Rais 'Am NU merupakan manifestasi ketaatan dan pelaksanaan ajaran suci agama. Sehingga, direspons dengan semangat jihad yang menyala dan berkobar, walaupun harus merelakan jiwa dan raga.

Pada derajat ini, nasionalisme santri tidak bisa diragukan lagi. Perintah agama yang menganggap ḅubb al-wațan, cinta tanah air, merupakan sebagian dari iman semakin menegaskan integrasi antara berjuang mempertahankan tanah air dan berjihad membela agama dan kebenaran. Ketika semangat jihad sudah membara,

${ }^{13}$ Ibid., hlm. 33. 
maka dunia dan seisinya ini terasa kecil dibanding keridaan dari zat pencipta alam semesta ini.

Selain itu, nasionalisme juga bisa dilihat dari konsepsi dar al-Islam yang pernah dicetuskan oleh NU, sebuah organisasi terbesar di Indonesia yang berbasis tratdisonal dan pesantren. NU dalam sebuah muktamarnya pernah mengeluarkan sebuah fatwa tentang dar al-Islam, di mana Indonesia merupakan negara Islami yang wajib dibela dan dipertahankan. Juga, tentang konsep kepemimpinan Soekarno, yang pada masa awal pernah menjadi perdebatan sengit. Tentang posisi Presiden Soekarno, dimaknai NU sebagai waliy al-amri ad-daruriy bi asy-syawkah. Yakni, penerimaan Presiden Soekarno sebagai orang yang berhak mengurusi persoalan umat, di tengah perdebatan ormas Islam lainnya tentang boleh tidaknya posisi presiden dalam sistem syari'at Islam.

Sistem nilai dalam pesantren tersebut apada akhirnya menjadi sebuah habitus pembentuk peradaban masyarakat di Indonesia. Diakui atau tidak, berbagai sistem nilai yang dibangun oleh pesantren menjadi satu faktor pembentuk peradaban Islam di Indonesia. Corak Islam toleran, sebagaimana disebut di awal tulisan ini, tidak hadir dalam ruang hampa. Ia dibangun oleh sebuah sistem tradisi yang berjalin kelindan dengan kehidupan manusia di dalamnya.

Dalam dimensi lain, pesantren telah memberikan karakter unik bagi pendidikan dan peradaban Islam di Indonesia. Karakter kebersahajaan, nasionalisme, tradisi keilmuan, dan pelestarian tradisi adalah beberapa karakter yang masih terwariskan pada masa kekinian. Sehingga, karakter tersebut adalah habitus, sebagaimana konsepsi Bourdieu, yang telah melewati berbagai tantangan dan persaingan nilai selama berabad-abad lamanya.

\section{Simpulan}

Peradaban Islam di Indonesia tidak bisa lepas dari pendidikan sebagai proses pembentuknya. Dalam hal ini, 
pesantren memiliki peran penting dalam membentuk "habitus" sosial masyarakat Islam di Indonesia sebagai mayoritas. Sistem nilai dari pesantren, seperti kebersahajaan, tradisi keilmuan, serta penjaga budaya dan nasionalisme membentuk perilaku masyarakat yang saat ini masih terwariskan. Sehingga, pesantren merupakan mozaik penting dalam peradaban Islam di Indonesia, yang memberikan andil dalam menciptakan tradisi keberagamaan yang toleran. [] 


\section{DAFTAR PUSTAKA}

Bourdieau, Pierre, Outline of Theory of Practice, Cambrige: Cambrige University Press, 1997.

Bourdieu, Pierre dan Terry Eagleton, "Doxa and Common Life: an Interview", Mapping Ideology, New York: Verso, 1994.

Dhofier, Zamakhsyari, Tradisi Pesantren: Studi Tentang Pandangan Hidup Kyai, Jakarta: LP3ES, 1985.

George, Ritzer, Sociological Theory, Singapore: The McGraw Hill Companies, 1960.

Lechte, John, 50 Filsuf Kontemporer, Yogyakarta: Kanisius, 2001.

Madjid, Nurcholish, Bilik-bilik Pesantren, Jakarta: Paramadina, 1997.

Mas'ud, Abdurrahman, dkk., Dinamika Pesantren dan Madrasah, Yogyakarta: Pustaka Pelajar, 2002.

Nawawi, “Sejarah Perkembangan Pesantren”, Jurnal Ibda, STAIN Purwokerto, 2006.

Swartz, David, Culture and Poer: the Sociology of Pierre Bourduen, Chicago: The University of Chicago, 1997.

Zuhairini, dkk., Sejarah Pendidikan Islam, Jakarta: Bumi Aksara, 1997.

Zuhri, Saifuddin, Sejarah Kebangkitan Islam dan Perkembangannya di Indonesia, Bandung: al-Ma'arif, 1979. 
